THE STRICKEN PEACOCK 


\section{THE STRICKEN PEACOCK}

\section{ANGLO-BURMESE RELATIONS}

1752-1948

by

MAUNG HTIN AUNG

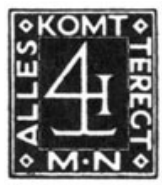

THE HAGUE

MARTINUS NIJHOFF

1965 
ISBN 978-94-015-0420-1 ISBN 978-94-015-1045-5 (eBook) DOI $10.1007 / 978-94-015-1045^{-5}$

Copyright, 1965, by Martinus Nijhoff, The Hague, Netherlands All rights reserved, including the right to translate or to reproduce this book or parts thereof in any form. 


\section{TABLE OF CONTENTS}

Preface VII

The Peacock Symbol XI

I. The Pattern of Burmese History 1

II. Burmese Attempts at Diplomacy (1752-1819) 12

III. Failure of Diplomacy and the Anglo-Burmese Wars 28

IV. The Humiliation of King Mindon 52

V. Allegations of Secret Diplomacy and End of the Burmese Kingdom $\quad 68$

VI. The Consequences of British Rule and Japanese Occupation 94

VII. The Triumph of Diplomacy and Regaining of Independence 122

$\begin{array}{lll}\text { Appendix I. The Alaungpaya Dynasty } & 128\end{array}$

Appendix II. Governor-Generals of India during the Alaungpaya Period 129

$\begin{array}{lr}\text { Bibliography } & 126\end{array}$

$\begin{array}{ll}\text { Index } & 130\end{array}$ 


\section{PREFACE}

It was the unanimous verdict of British and American historians that the Kings of Burma were arrogant barbarians, absolutely without any knowledge of diplomacy and diplomatic practice, whose foolish actions forced the British to annex the country. Although the unanimity was broken in 1962 by Miss Dorothy Woodman in her brilliant work The Making of Burma, it still remains the majority verdict, and has even been re-affirmed. Mr. E. C. V. Foucar, who expressed his verdict in 1944 in They Reigned in Mandalay, confirmed it in 1963 in Mandalay the Golden. Professor John F. Cady, who fully agreed with the verdict in 1960 in A History of Modern Burma, has modified his opinion only with regard to the Second Anglo-Burmese War, in his recently published work South-East Asia: Its Historical Development. The verdict is an ex parte one, because no consideration was given to the Burmese point of view or to the Burmese sources of history. Moreover, it was arrived at on false and fraudulent evidence.

The British fought three wars against the Burmese during the period 1824-1886. For the First war, both the British and the Burmese must share the blame, and except for the great disparity in arms, it was a fair fight. But after gaining two out of the three Burmese maritime provinces as spoil of victory, the British mercantile interests cast a greedy eye on the rest of the country and began to manufacture falsc evidence which would justify the re-opening of hostilities against the Burmese monarch. Both the Second and the Third wars were atgrgessive wars, and as even their carefully prepared false propaganda could not hide fully the nakedness of their aggression, they resorted to suppressing and falsifying the evidence. Miss Dorothy Woodman in her above-mentioned work carefully showed how important and damning passages were deleted from official papers submitted to the Parliament in London. 
In defending the actions of the Burmese Kings, I do not mean to say that they were saintly persons moved by a spirit of meekness and humility. My family knew only too well that Burmese Kings sometimes could be unappreciative and merciless, for many of my ancestors lost their heads after long and faithful service; to cite but one instance, my great-grandfather, who was left as the military Governor of Arakan after the great Bandula had marched away to meet the main British army at Rangoon, was promptly beheaded in 1825 for failing with his small garrison to stem the British advance. But the Burmese Kings were no more despotic than other oriental monarchs and the kings of Europe in medieval times, and as in the case of all despots they were sometimes enlightened. At least they were patriots and were not mad or foolish by any means. The taint of madness has been alleged against the Alaungpaya dynasty by British historians, but the Kings before 1824 never went insane. Bagyidaw and Tharrawaddy did become mad towards the end of their reigns, but even the sanest of British monarchs would have lost his sanity if he were in their position. Pagan took to drink, and Mindon did not lose his reason, because immensely devout, he had the solace of his religion. Theebaw did not go mad because his inheritance was, as one of his contemporaries described, a mere fistfull of territory, and moreover, it was always on the verge of being lost.

Contrary to the views of British historians, the Burmese never underestimated the power and might of the British. After all, by 1824 the British had conquered not only the Indian subcontinent but also Ceylon. However, the Burmese took a chance and hoped that against fearful odds they would be able to snatch a victory. After their defeat in 1826, they knew that they were no match for the British. The epithet "foolish" has been applied by all European writers to King Theebaw. Kipling voiced the general opinion of the British when he wrote that Theebaw the Burma King

Did a very foolish thing in rejecting the British ultimatum, thinking that British troops would never be able to come up to "far Mandalay." In actual fact, British steamers were at that time plying freely up and down the river past Mandalay itself to Bhamo in the far north. As with the Second war, the Burmese neither desired nor did they ever prepare to fight the Third war. "King Theebaw's sins were many and great," Lord Randolph Churchill's secretary wrote in a despatch; but surely foolishness was not one of them, and he tried his utmost to avoid a war with the British. In the following pages I have endeavoured to present the 
Burmese case and explain the circumstances which compelled Theebaw to reject the fateful British ultimatum in 1885 which cost him his kingdom.

The materials on which the present work is based were gathered in 1957 and 1958 when, as Chairman, I was procuring for the Burma Historical Commission, and through three research assistants, photostat copies of relevant papers and documents preserved in the India Office Library in London. Other preoccupations prevented me from completing this book, and when Miss Dorothy Woodman's work came out, I wondered whether it was still necessary to complete it. But Miss Woodman's remark "Until a Burmese historian provides a detailed account of what was happening at that time in Ava, we have to depend on second-hand sources for any evaluation of the balance of power in the Court," ${ }^{1}$ encouraged me to think that there was still room for my own contribution towards a fuller knowledge of the history of Burma in the troubled nineteenth century. I must hasten to say, however, that the opinions expressed in this book are not in any way the views of the Burma Historical Commission, as I resigned my Chairmanship in 1959.

In relating the history of Burmese politics during the period 18861948 , it became necessary for me to mention the work of two of my three elder brothers, U Tin Tut and U Kyaw Myint. In doing so, however, I tried to curb my natural admiration for them and attempted at the same time to be detached and restrained. It is their misfortune that the author of this present work should be their youngest brother.

I have been able to complete the book at long last in hours of happy leisure as a scholar-in-residence at Columbia University in the School of International Affairs, and I take this opportunity to express my gratitude to Dean Andrew W. Cordier and President Grayson Kirk.

Uris Hall,

Maung Hin Aung

Columbia University in the

City of New York.

June 22, 1964.

1 Dorothy Woodman, The Making of Burma, The Cresset Press, London, 1962, p. 146. 
NOTE

THE PEACOCK SYMBOL

\author{
The Golden Peacock shall be stricken, \\ And the White Heron shall occupy its shady pool. \\ But a sudden storm of lightning \\ Will drive the White Heron away. \\ Ancient Burmese Prophecy
}

Since the beginning of their history the Burmese used the figure of a Peacock in its Pride as their national emblem. There exists no definite evidence that the ancestors of the Burmese ever worshipped a totem, but if they did, it must have been the Peacock. When a monarchy was later evolved, the Kings used the Peacock as the emblem of their authority, and their banner carried the figure of a Dancing Peacock embroidered in heavy gold thread on a white or green background. After the introduction of Buddhism into the country, the Kings claimed that they belonged to the Sun clan, to which the Buddha himself belonged, and as the Buddhist Jatakas mentioned that the image of a Dancing Peacock was embossed on the face of the sun, they now explained that their banner proclaimed their membership of the solar race. The Peacock was always considered to be a lucky bird, and its feathers often decorated the walls of a Burmese house. The King in his palace had a number of thrones, the most important of which were the Lion Throne and the Peacock Throne. Whereas the Lion Throne was placed in the formal audience hall, the Peacock Throne was placed in the informal audience chamber. When King Mindon introduced a silver coinage, the figure of a Dancing Peacock appeared on his silver rupee. Centuries before Mindon, however, the Burmese gold-and-silver-smiths had already begun to use the Peacock as a favourite motif. Although to the Burmese, the Peacock symbolized their fierce pride and militant nationalism, to their unsympathetic British conquerors it represented Burmese vanity and conceit.

The guerrillas of 1886 continued to use the Peacock banner, but the fiery young student leaders at the University of Rangoon attempted to modify the national symbol by substituting the figure of a Fighting Peacock. However, both General Aung San's Independence Army 
and Dr. Ba Maw's Independent State used the Dancing Peacock as their symbol on their flags. When in 1947 independence had been decided upon, and the constitution for the new State of Burma was being drawn up, two objections were raised against the retention of the Dancing Peacock as the national symbol. The new State being a republic, the Peacock which had been the personal emblem of Kings should not be used; Burmese nationalism was no longer militant but friendly and benevolent, and the Peacock symbol was associated with militant nationalism of the past. There was also a suggestion that the Peacock should be replaced by the Crested Lion which guards Burmese pagodas, but again there came the objection that the Lion also would not fit in with the friendly mood of the new nationalism. Finally a simple design in red and blue with white stars representing the federal states of the republic was adopted as the new national symbol and flag. Only the Crested Lion found a place in the new State seal. Thus the Peacock was finally discarded.

According to an old Burmese prophecy given in the form of a series of jingles as in the prophecies of Nostrodamus, the Golden Peacock, after a long fight with the Red Sheldrake would emerge victorious. The Brahminee-Duck or the Ruddy Sheldrake was the symbol used by the Mon Kings on their banner. The prophecy went on to say that after a time, the Peacock "would become stricken" and the White Heron would usurp the shady pool, only to be driven away later by a sudden storm. 